\title{
농업분야의 동남아 개발 수요와 한국의 ODA 추진방향 모색
}

김 태 윤 (대외경제정책연구원 부연구위원)

\section{목 차}

I. 서론

II. 동남아 농업부문의 주요 특징과 의미

III. 동남아 농업분야 ODA의 개발 수요과 국제사회의 지원현황

1. 동남아 농업분야 ODA의 개발 수요

2. 국제사회의 지원현황

$\mathrm{IV}$. 동남아 농업분야에 대한 한국의 ODA 추진방향 모색

\section{I . 서론}

개발도상국과 개발협력 사업을 추진함에 있어 농업분야는 상대적으로 중요한 위치를 차지 한다. 이는 개발도상국에서 농업이 차지하는 비중이 다른 제조업이나 서비스업보다 상대적으 로 높기 때문이기도 하지만 해당분야에 종사하는 인구가 절대적으로 많기 때문이다. 다시 말 하면 농업이 창출하는 직접적인 생산액에 비해서 상대적으로 많은 사람들이 농업에 종사하고 있기 때문에 개발협력에 있어서 이러한 인적 요인을 고려하는 것이 절실히 필요한 상황이다. 
〈표 1〉 동남아 주요국의 농업생산액과 농업종사자 비중(2011년)

\begin{tabular}{c|c|c|c}
\hline 국가 & $\begin{array}{c}\text { 농업생산액 } \\
\text { 비중(\%) }\end{array}$ & $\begin{array}{c}\text { 농업종사자 } \\
\text { 비중(\%) }\end{array}$ & 비고 \\
\hline 라오스 & 28.4 & 75.3 & $\begin{array}{c}\text { 농업생산액은 2010년 기준 } \\
\text { 농업종사자는 2005년 기준 }\end{array}$ \\
\hline 미얀마 & 36.4 & 51.1 & $\begin{array}{c}\text { 농업생산액은 2010년 기준 } \\
\text { 농업종사자는 1997년 기준 }\end{array}$ \\
\hline 말레이시아 & 11.9 & 11.6 & - \\
\hline 베트남 & 22.0 & 47.4 & - \\
\hline 인도네시아 & 14.7 & 33.5 & - \\
\hline 캄보디아 & 34.6 & 71.3 & $\begin{array}{c}\text { 농업종사자 비중은 전체 고용인구 } \\
\text { 중 농업에 종사하는 사람 비중임. }\end{array}$ \\
\hline 태국 & 10.9 & 38.4 & 농업생산액은 2010년 기준 \\
\hline 필리핀 & 12.8 & 30.7 & - \\
\hline 평균 & 21.4 & 44.9 & - \\
\hline
\end{tabular}

자료: $\mathrm{ADB}(2012)$ 를 이용하여 저자 작성

일례로〈표 1〉은 동남아 주요국의 총 GDP 중 농업생산액의 비중과 전체 노동인구 중 농업 종사자의 비중을 정리한 것이다. 동남아 주요국의 평균을 살펴보면 농업생산액 비중은 약 $21.4 \%$ 인 반면 농업종사자의 비중은 $44.9 \%$ 로 상당히 높은 수준임을 알 수 있다. 이는 생산되 는 부가가치를 기준으로 볼 때, 다른 산업보다 농업에 종사하는 인원수가 상대적으로 많음을 의미하는 것이다. 특히 흔히 CLMV로 불리는 캄보디아, 라오스, 미얀마, 베트남의 농업 종사 자 비중이 상당히 높음을 알 수 있다.

한편, 개발도상국이 한 단계 진전된 산업화된 국가로 발전하기 위해서는 사회적으로 필요한 산업부문을 개발하는 것이 중요하며, 이를 뒷받침하기 위해서 기존의 농업부문 노동력의 질적 인 성장을 위한 정책적 조치(예 : 교육, 훈련 지원 등)가 상당히 중요하다. 일례로 Lucas and Verry(1999)는 말레이시아의 신경제정책(NEP : New Economic Policy)을 통한 경제전환 과 정에서 농업부문의 성과가 높았고, 지역개발과 함께 노동력에 대한 교육 및 훈련 등을 통하여 농업노동력이 다른 산업으로 전환이 이루어졌으며, 이것이 말레이시아의 빈곤감소에 기여함과 동시에 산업구조 조정에 긍정적 역할을 수행하였다고 평가하고 있다(p. 145, 170-71).

본 연구는 이러한 농업부문에 대한 개발협력의 중요성을 다시 한 번 인식하고자 하는 차원 에서 출발하였다. 특히 한국이 지난 20 여 년간 동남아에 대한 개발협력 사업을 지속적으로 추 진하였기 때문에 농업분야에 대한 현지의 개발수요와 주요 선진국들의 지원현황을 비교하는 
것은 의미가 있다고 하겠다. 이는 향후 한국의 농업분야에 대한 $\mathrm{ODA}$ 추진방향을 점검하는데 도 기여할 것이다. 이를 위해 본 연구는 크게 3 부분으로 구성되어 있다. 제 2 장에서는 동남아 농업부문의 주요 특징과 그 의미를 간단히 살펴볼 것이다. 제 3 장에서는 동남아 농업분야 ODA 의 개발수요와 국제사회의 지원현황을 점검할 것이다. 동남아 농업부문의 특징을 통한 개발수 요를 파악함과 동시에 기존의 국내연구를 통한 개발수요를 이해한 후 국제사회의 지원 현황과 추세를 검토할 것이다. 이를 종합하여 제 4 장에서는 한국의 동남아에 대한 농업 부문 ODA의 추진방향을 모색하고자 한다.

\section{II. 동남아 농업부문의 주요 특징과 의미}

동남아 농업부문의 주요 특징 중 하나는 앞의 〈표 1〉에서 언급한 바와 같이 전체 고용 인구 에서 농업인구가 차지하는 비중이 $44.9 \% 1$ 로 상당히 높고, 동시에 전체 GDP에서 농업생산액 이 차지하는 비중도 $21.4 \% 2$ 로 높다는 것이다. 그리고〈표 2〉에서 보는 바와 같이 곡류와 육 류 생산현황을 살펴보면, 2011년 기준 동남아 국가들의 곡류생산량 평균은 ha당 $3,930.5 \mathrm{~kg}$ 인 데, 베트남이 $5,383 \mathrm{~kg}$ 으로 가장 높고, 캄보디아가 $2,925.4 \mathrm{~kg}$ 으로 가장 낮은 생산성을 보이고 있다. 참고로 2011년 한국의 곡류생산량이 ha당 약 $7,037.9 \mathrm{~kg}$ 임을 감안하면 평균적으로 한국 의 약 $55.8 \%$ 수준임을 알 수 있다. 또한 2011년 기준 동남아 국가들의 연간 육류 생산량 평균 은 약 2 백만 톤이며, 베트남이 약 4.1 백만 톤으로 가장 높고, 라오스가 14 만 톤으로 가장 낮은 수준이다. 한국의 2011 년 육류 생산량이 약 1.81 백만 톤 수준임을 감안할 때 동남아의 육류생 산량은 평균적으로 한국보다 다소 높은 수준이다. 인구 1 인당 육류 생산량을 살펴보면, 동남 아의 경우 평균 $31.4 \mathrm{~kg}$ 수준인데, 이는 2011년 한국의 1 인당 육류생산량 $36.2 \mathrm{~kg}$ 보다 다소 낮 은 수준이다.

1) 2011년 기준 한국은 전체 고용 인구에서 농업인구가 차지하는 비중이 $6.1 \%$ 수준이다.

2) 2011년 기준 한국은 전체 GDP에서 농업생산이 차지하는 비중이 $2.4 \%$ 수준이다. 
〈표 2〉 동남아 주요국의 연간 곡류 및 육류 생산량(2011년)

\begin{tabular}{c|c|c|c|c}
\hline \multirow{2}{*}{ 국가 } & \multirow{2}{*}{$\begin{array}{c}\text { 단위당 } \\
\text { 곡류생산량 } \\
(\mathrm{Kg} / \mathrm{Ha})\end{array}$} & $\begin{array}{c}|c| \\
\text { 윤간 생산량 } \\
(\text { 톤) }\end{array}$ & $\begin{array}{c}\text { 인군간 } \\
\text { 1인당 생산량 } \\
(\mathrm{kg})\end{array}$ & $\begin{array}{c}\text { 총 인구 } \\
\text { (천 명) }\end{array}$ \\
\cline { 3 - 4 } & $4,045.0$ & $136,481.00$ & 21.7 & 6,288 \\
\hline 라오스 & $3,879.8$ & $1,978,143.75$ & 31.7 & 62,417 \\
\hline 미얀마 & $3,919.5$ & $1,691,074.90$ & 59.2 & 28,553 \\
\hline 말레이시아 & $5,383.0$ & $4,138,055.00$ & 46.3 & 89,316 \\
\hline 베트남 & $4,886.1$ & $2,984,550.00$ & 12.4 & 241,030 \\
\hline 인도네시아 & $2,925.4$ & $198,412.00$ & 13.1 & 15,103 \\
\hline 캄보디아 & $3,065.0$ & $2,402,619.80$ & 37.5 & 64,076 \\
\hline 태국 & $3,340.6$ & $2,827,092.50$ & 29.5 & 95,856 \\
\hline 필리핀 & $3,930.5$ & $2,044,553.62$ & 31.4 & - \\
\hline 평균 & &
\end{tabular}

자료: FAOSTAT을 이용하여 저자 작성(http : //faostat3.fao.org/home/index.html\#HOME),

동남아 주요 국가들의 농업 부문 수출입액을 살펴보면 다음의 〈표 3〉과 같다. 2010년 기준 동남아 주요 국가들의 수출입을 평균적으로 살펴볼 때, 수출은 약 121.5 억 달러이고 수입은 63.8억 달러로 약 57.7억 달러의 무역수지 흑자를 기록하였다3). 국가별로 살펴보면 수출의 경우 인도네시아가 약 307 억 달러로 가장 많고 다음으로 말레이시아와 태국이 약 259 억 달러 수준이다. 수입의 경우 말레이시아가 약 140 억 달러로 가장 많고 인도네시아가 125 억 달러로 그 다음을 차지한다. 동남아 주요 국가 중 인도네시아, 태국, 말레이시아, 베트남이 농업부문 에서 무역수지 흑자를 기록하고 있으며 필리핀, 미얀마, 캄보디아, 라오스는 무역수지 적자를 기록하고 있다. 특히 필리핀은 주식인 쌀의 수입이 상대적으로 높은 편인데, 2010년 기준 약 24.6 억 달러의 높은 적자를 기록하였다.

3) 참고로 2010년 한국의 농업부문은 수출 38.5억 달러, 수입 188 억 달러로 149.5 억 달러의 무역수지 적자를 기록하였다. 
〈표 3〉 동남아 주요국의 농업 부문 수출입액(2010년)

\begin{tabular}{c|c|c|c}
\hline 국가 & $\begin{array}{c}\text { 수출 } \\
\text { (천 달러) }\end{array}$ & $\begin{array}{c}\text { 수입 } \\
\text { (천 달러) }\end{array}$ & $\begin{array}{c}\text { 무역수지 } \\
\text { (천 달러) }\end{array}$ \\
\hline 라오스 & 77,007 & 289,395 & $-212,388$ \\
\hline 미얀마 & 645,528 & $1,227,831$ & $-582,303$ \\
\hline 말레이시아 & $25,912,684$ & $14,080,149$ & $11,832,535$ \\
\hline 베트남 & $10,411,031$ & $9,072,748$ & $1,338,283$ \\
\hline 인도네시아 & $30,722,359$ & $12,474,853$ & $18,247,506$ \\
\hline 캄보디아 & 161,682 & 639,426 & $-477,744$ \\
\hline 태국 & $25,894,955$ & $7,433,144$ & $18,461,811$ \\
\hline 필리핀 & $3,362,925$ & $5,827,555$ & $-2,464,630$ \\
\hline 평균 & $12,148,521,38$ & $6,380,637,63$ & $5,767,883,75$ \\
\hline
\end{tabular}

자료: FAOSTAT을 이용하여 저자 작성(http : //faostat3,fao.org/home/index.html\#HOME).

이러한 동남아 주요 국가들의 농업부문의 현황을 통하여 그 의미를 살펴보면 다음과 같이 정리할 수 있다. 첫째, 주곡인 곡류의 생산성이 여전히 낮은 수준이다. 동남아 대부분의 국가 에서 2 모작 나아가 일부지역에서 3 모작까지 가능한 상황임에도 불구하고 단위당 생산량이 한 국의 절반 정도 수준인데, 이는 전반적으로 생산기반이 여전히 열악함을 의미한다. 국가별 기 후특성에 따라 생산기반이 다를 수 있겠지만, 관개시설이나 비료 등과 같은 생산요소에 대한 투자가 상대적으로 필요한 상황이다. 또한 생산된 곡류의 부가가치를 창출하기 위한 가공시설 에 대한 수요도 장기적으로 높다고 할 수 있다. 둘째, 육류 생산량이 적지 않다는 점이다. 전 체 생산량 기준으로 살펴보면 베트남과 인도네시아가 높은 편인데, 1 인당 생산량으로 살펴보 면 말레이시아와 베트남 및 태국이 상대적으로 높은 편이다. 육류의 경우 곡류에 비하여 상대 적으로 생산보다는 가공시설과 상품개발 및 해외시장 진출 등 부가가치를 향상시키기 위한 개 발수요가 높다고 할 수 있다. 셋째, 일부 동남아 국가들은 개발도상국임에도 불구하고 농업부 문에서 무역수지 적자를 기록하고 있다는 점이다. 대부분 주곡인 쌀이 부족하기 때문에 이를 충당하기 위한 것으로 이해할 수 있다. 하지만 일부 국가의 경우 자국 내 곡류의 가공시설이 부족하기 때문에 인근 다른 국가의 가공시설을 이용하는 과정에서 발생하기도 한다. 따라서 기본적으로 농업부문의 적자를 개선할 수 있는 다양한 방안이 필요한 상황이다. 일례로 곡류 의 생산성 증대와 함께 소규모 가공시설을 갖춤으로써 곡류 가공류에 대한 수입의존도를 낮추 는 것도 하나의 방안이 될 수 있다. 넷째, 일부 동남아 국가들은 농업부문의 무역수지 흑자 규 모가 상당히 높은 편이지만, 주요 수출품은 몇 가지 품목으로 한정되어 있다는 점이다. 인도네 시아는 주로 카카오와 커피 원두를 수출하고 있으며, 말레이시아는 주로 팜 오일을 수출하고 있고, 태국은 주로 쌀을 수출하고 있다. 따라서 이들 국가에서 지속적으로 농산물을 수출하고 
동시에 보다 더 큰 부가가치를 창출하기 위해서는 가공, 상품개발, 수출농산품 다각화와 같은 전략이 필요할 것으로 판단된다.

\section{III. 동남아 농업분야 ODA의 개발 수요과 국제사회의 지원현황}

\section{1. 동남아 농업분야 ODA의 개발 수요}

농업분야에 대한 동남아의 ODA 개발 수요는 다양한 측면에서 살펴볼 수 있다. 우선 앞의 2 장에서 살펴본 바와 같이 주요 품목에 대한 생산과 수출입 현황을 살펴보고 다른 국가와의 상 대적 비교를 통하여 향후 필요한 분야를 정성적으로 파악할 수 있다. 이를 통하여 살펴보면, 우선 곡류의 경우 생산성 향상을 위한 기반시설 및 투입재에 대한 수요가 상대적으로 높다는 것이다. 곡류에 대한 가공 및 저장시설은 식량 확보뿐만 아니라 수출의 부가가치 창출과도 연 계되어 있다. 육류의 경우 가공 및 유통시설에 대한 수요가 장기적으로 높을 것으로 판단된다. 또한 필리핀, 캄보디아, 미얀마와 라오스의 경우 농업부문의 무역수지 적자를 해소하기 위하 여 수출농업 육성과 같은 다양한 수출지원 정책이 필요할 것으로 판단된다. 농산물 수출의 경 우 몇 가지 소수의 품목이 대부분을 차지하기 때문에 상품개발을 통하여 수출품목을 다양하게 하고 보다 부가가치를 창출할 수 있는 수출 가공시설에 대한 수요가 높을 것으로 판단된다.

농업부문의 다양한 지수를 이용하고 보다 발전한 국가와의 상대적 비교를 통해 해당국가의 잠재적 개발수요를 정량적으로 측정할 수 있다. 일례로 권율 외(2012)는 농업부문의 ODA 개 발협력 수요를 도출하기 위하여 통계자료를 이용하여 지수화 작업을 수행하였다. 세계식량기 구(FAO)에서 제공하는 농업지수 중 전체 농경지에서 관개시설이 차지하는 비중(Total Area Equipped for Irrigation/Agricultural Land)과 농업자본 대비 농기계 비중(A Share of Machinery \& Equipment in Agricultural Capital)을 농업지수로 사용하였다. 이를 이용하여 동남아 개별 국가에 대한 농업지수를 계산한 후 해당 국가보다 한 단계 발전한 국가의 농업지 수 평균과 비교하여 그 차이만큼을 개발수요, 즉 수원국의 필요성으로 판단하였다. 예를 들면, 캄보디아의 경우 베트남, 인도네시아, 필리핀을 한 단계 발전한 국가로 가정하고 이들 3 개 국 가의 농업부문 평균과 캄보디아의 농업지수를 비교하여 그 차이만큼을 개발수요로 본 것이다. 필리핀의 경우 말레이시아, 태국을 한 단계 발전한 국가로 가정하고 이들 2 개 국가의 농업부 문 평균과 필리핀의 농업지수를 비교하여 그 차이만큼을 개발수요로 판단하였다. 그 결과 동 
남아의 5 개 조사대상 국가 중 농업부문의 개발수요는 캄보디아, 동티모르, 필리핀, 인도네시 아, 베트남 순으로 나타났다(권율 외, 2012, p. 83). 다만 농업내의 구체적인 협력분야에 대한 개발수요를 보여주기에는 한계가 있기 때문에 농업부문에 대한 선진 공여국과 한국의 지원현 황을 추가로 검토하였다.

김태윤 외(2012)에서는 농업부문에 대한 동남아 메콩 유역국가의 정책을 살펴봄으로써 현지 의 개발수요를 파악하였다. 태국은 농업부문에 대한 개발을 위해 왕실에서도 직접 참여하고 있으며, 수자원 분야와 연계된 농업개발에 대한 수요가 높은 편이다. 캄보디아는 농업이 국가 의 우선 개발 분야로 재원할당 비중이 가장 높은 분야이다. 라오스도 정부의 제 7 차 사회경제 발전계획(NSEDP)을 통하여 관개시설 및 농산물 가공산업 육성을 주요한 개발 분야로 판단하 고 있다. 미얀마는 농업부문에 대한 계획을 수립하고 있는 상황이며, 베트남은 5 개년 사회경 제개발계획(SEDP)를 통하여 농업의 현대화, 효율화 및 지속가능성에 초점을 두고 있다(김태 윤 외, 2012, p.66, 68).

\section{2. 국제사회의 지원현황}

아래〈그림 1〉에서 보는바와 같이 개발도상국에 대한 국제사회의 ODA 지원액은 1995 년 475.8억 달러에서 2010년 1,635.1억 달러로 지속적으로 증가해 왔다. 동시에 농업분야에 대한 국제사회의 ODA 지원액도 1995년 44.4억 달러에서 2010년 95.6억 달러로 꾸준히 증가하였 다. 하지만 전체 $\mathrm{ODA}$ 중 농업분야 $\mathrm{ODA}$ 의 비중을 살펴보면 2006년까지 감소하다가 이후에 다소 증가추세에 있음을 알 수 있다. 2000년대 중반까지 비중이 감소한 것은 세계은행이 2007년 작성한 보고서를 통하여 설명한 바와 같이 농업 이외의 이슈(성, 평등, 약자 보호 등) 에 대한 $\mathrm{ODA}$ 수요 증가, 공여국(선진국) 내 농민들의 반발, 화학비료 지원에 대한 환경론자들 의 반대 등에 기인한 측면이 있다(WB, 2007, p.42).

2000 년대 중반 이후에는 농업분야 ODA의 비중이 다시 증가하기 시작하였는데, 이는 개도 국의 빈곤감소를 위하여 국제사회가 보다 적극적으로 농업부문의 중요성을 인식한 것으로 이 해할 수 있다. 일례로 2000년 국제연합(UN)이 새천년개발목표(MDGs)를 선언한 이후 2015년 까지 절대빈곤과 기아퇴치에 대한 목표치를 달성하기 위하여 선진국을 중심으로 농업분야에 대한 지원이 지속적으로 증가한 것이다. 
〈그림 1〉 국제사회의 총 ODA와 농업분야 ODA 지원액 및 비중(1995-2010)

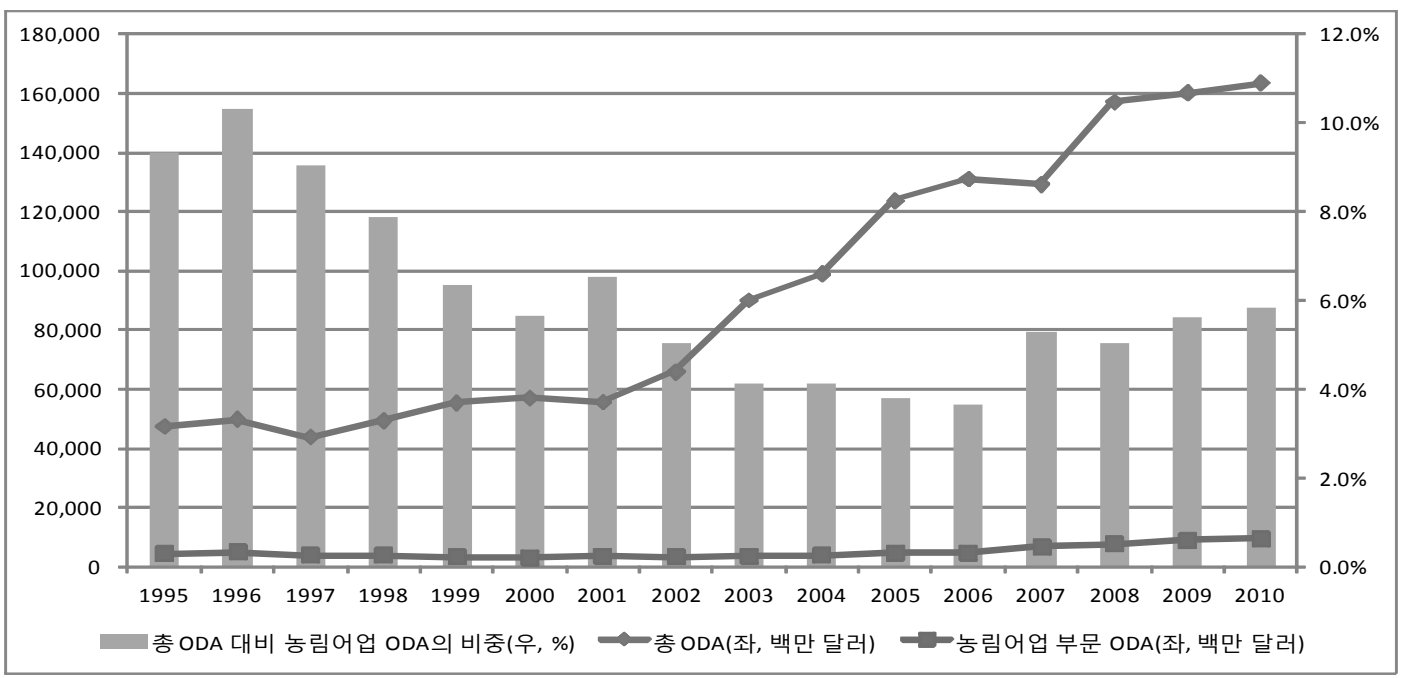

자료: $\mathrm{OECD}$ Creditor Reporting System 자료를 이용하여 저자 작성.

다음의 〈그림 2〉에서 보는 바와 같이 농업분야에 대한 ODA 지원 사업은 지속적으로 증가하 는 추세를 보이고 있으며, 전반적으로 $\mathrm{OECD}$ 의 $\mathrm{DAC}$ 회원국이 지원하는 사업이 다자간 기구가 지원하는 사업보다 다소 높은 상황이었다. 다만 2011년을 기점으로 다자간 기구의 농업부문에 대한 지원 사업이 $\mathrm{OECD} \mathrm{DAC} \mathrm{회원국의} \mathrm{지원} \mathrm{사업을} \mathrm{초과한} \mathrm{상황이다.}$

〈그림 2〉 OECD DAC 회원국과 다자간기구의 농업분야 지원 사업 추이(2002-2011)

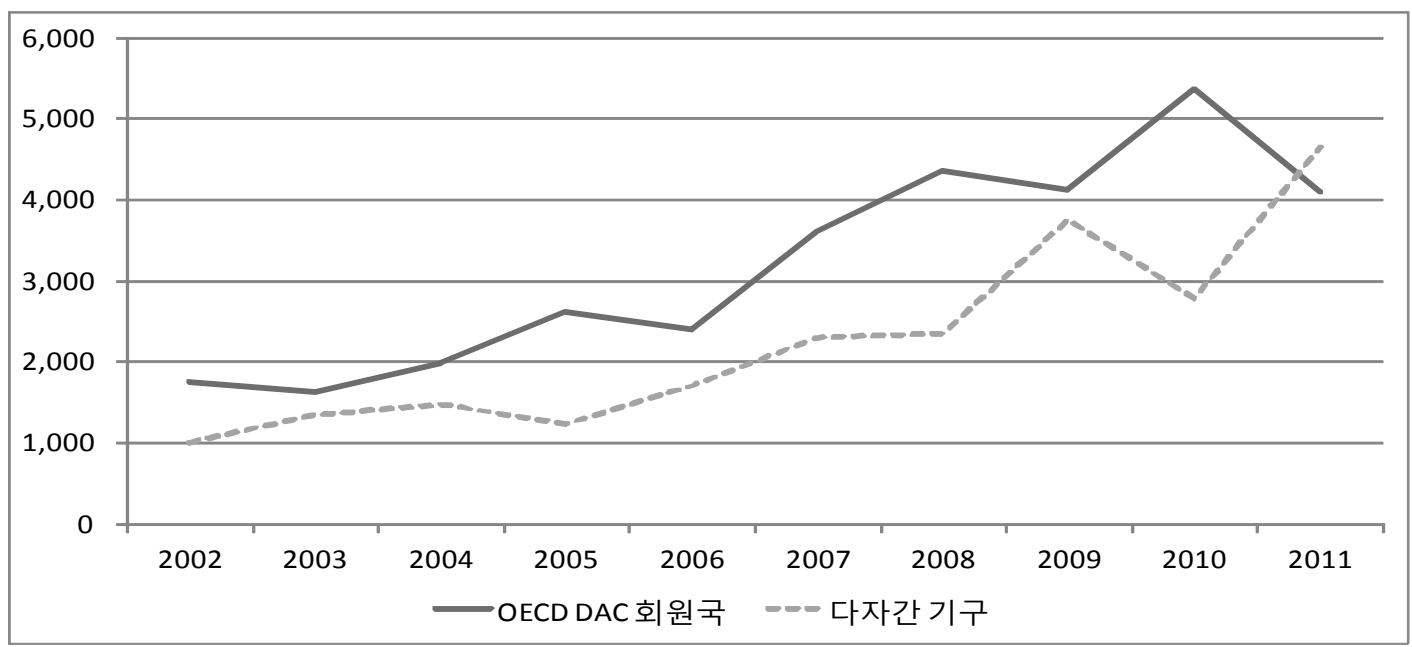

자료: OECD Creditor Reporting System 자료를 이용하여 저자 작성. 
다음의 〈그림 3〉에서 보는바와 같이 동남아 농업분야 ODA 지원액은 1996년 이후 급감하였 고, 20006년까지 전반적으로 감소하는 추세에 있다. 2007년 다시 증가하였지만 이후 2008년 글로벌 금융위기로 인하여 감소하였으며, 이후 세계적인 경기회복과 함께 다시 증가하는 추세 에 있다. 특히 2007년의 경우 베트남이 WTO에 가입하면서 국제사회의 베트남에 대한 지원이 크게 증가한 것에 기인한다.

〈그림 3〉 동남아 농업분야 ODA 지원액(1995-2010, 백만 달러)

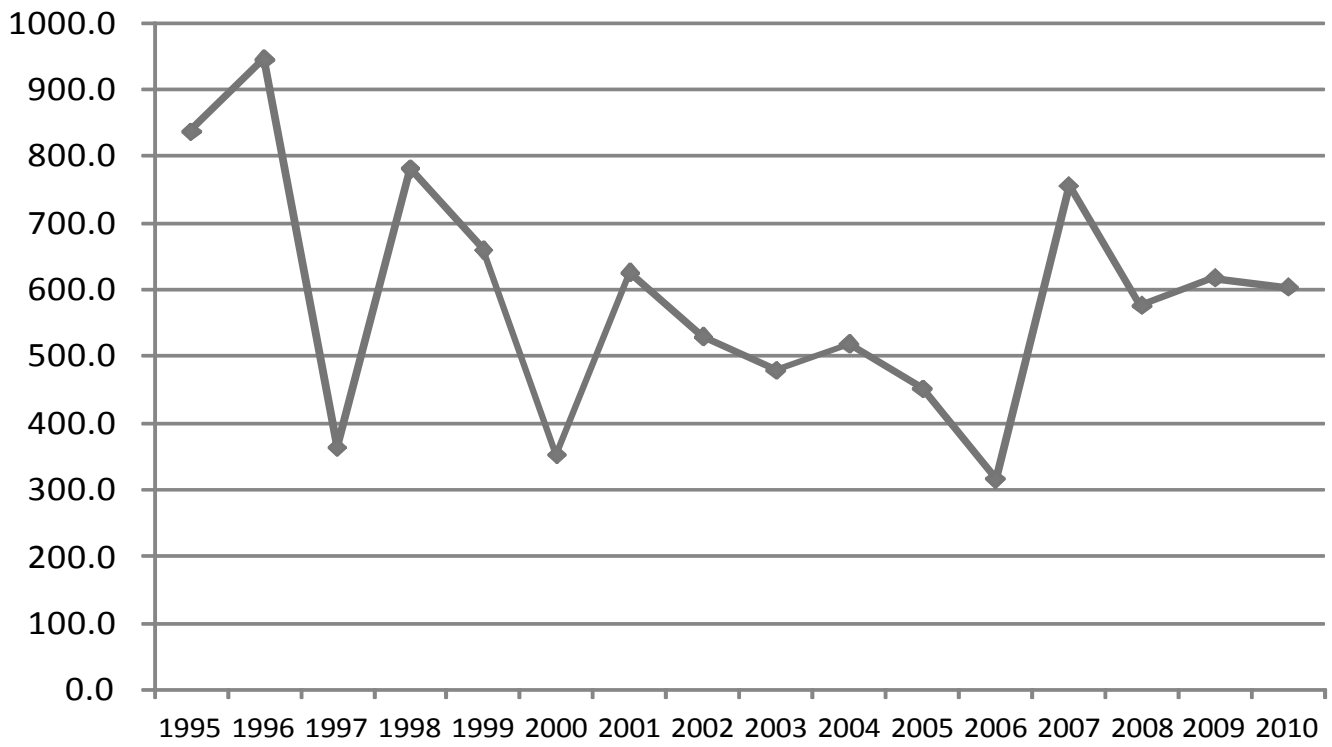

자료: OECD Creditor Reporting System 자료를 이용하여 저자 작성.

2011년 기준 동남아의 농업부문에 대한 지원액 중 OECD DAC 개별 회원국이 지원하는 것 이 약 $67 \%$ 이며, 다자간 기구를 통하여 지원하는 것이 약 $33 \%$ 수준이다(〈그림 4 〉참고). 즉 동 남아 지역은 전 세계적인 추세와는 달리 여전히 개별 국가차원에서의 지원 사업이 다자간 기 구를 통한 사업보다 2 배 정도 많음을 알 수 있다. 


\section{〈그림 4〉지원형태에 따른 비중(2011년)}

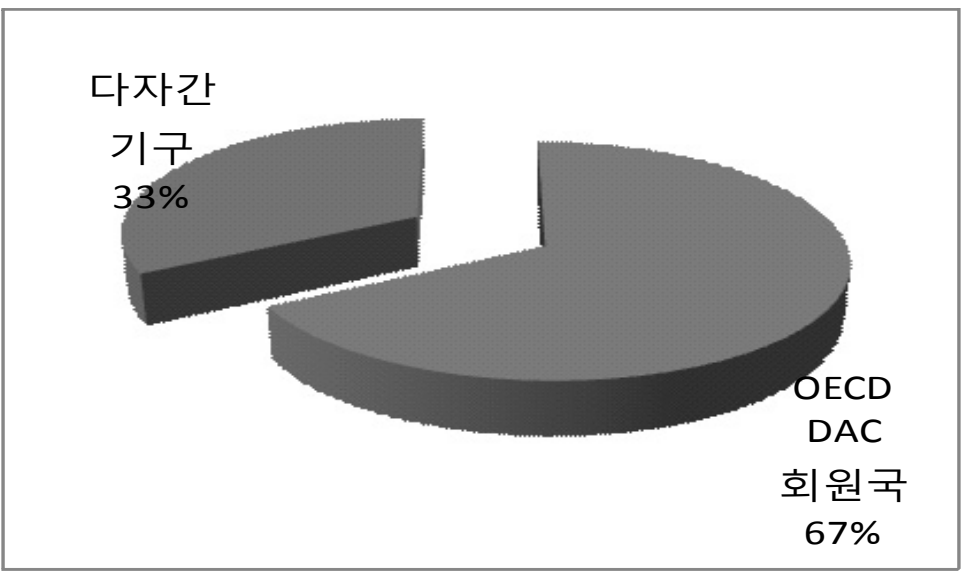

자료: OECD Creditor Reporting System 자료를 이용하여 저자 작성.

2011년 기준 지원형태에 따른 동남아 주요국별 ODA 사업현황을 살펴보면, 라오스의 경우 다자간 기구를 통한 지원 사업이 더 많았으며, 다른 동남아 국가는 개별국가들의 지원 사업이 더 많았음을 알 수 있다(〈그림 5〉 참고). 특히 라오스의 경우 2011년 $\mathrm{ADB}$ 의 2천만 달러 지원 사업인 '종 다양성 보존을 위한 GMS 경제회랑 프로젝트'로 인하여 다자간 기구를 통한 사업이 증가한 것이다.

〈그림 5〉 동남아 주요국별 지원형태에 따른 비중(2011년, 백만 달러)

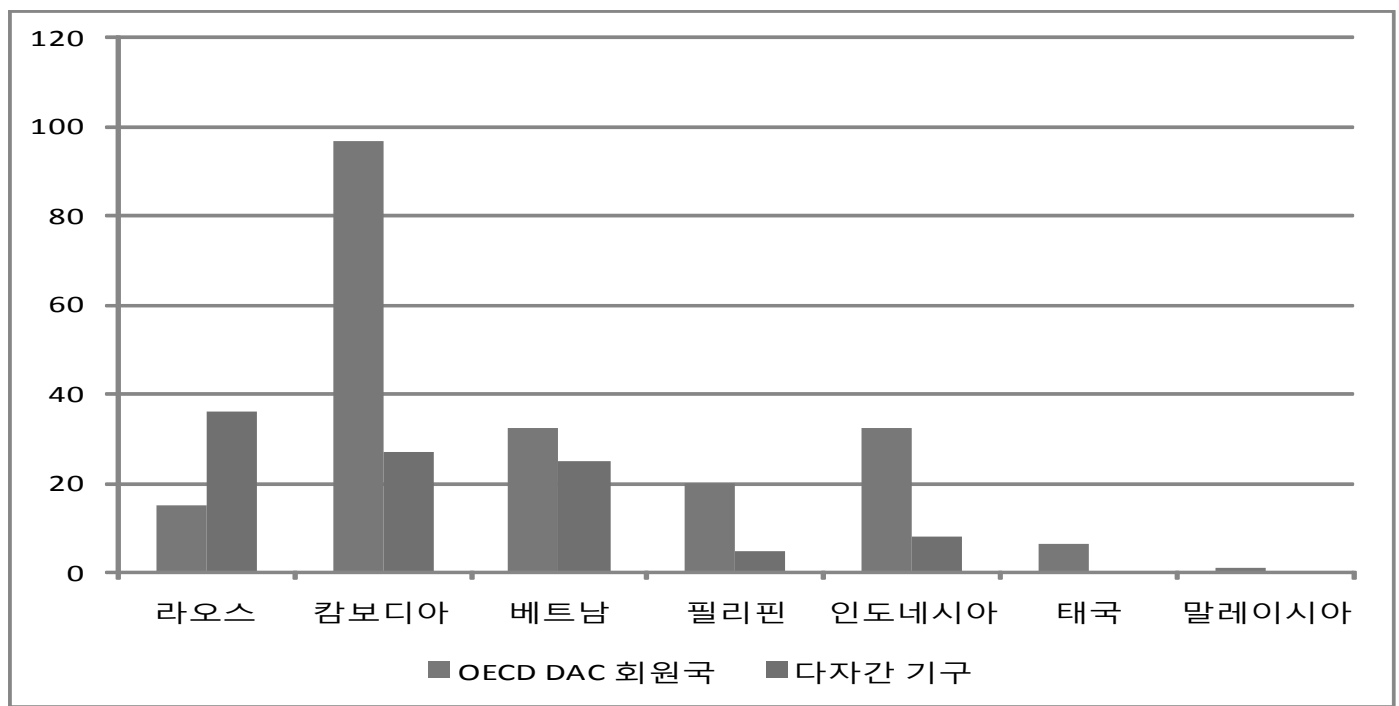

자료: OECD Creditor Reporting System 자료를 이용하여 저자 작성. 
2011년 기준, 공여국의 동남아에 대한 분야별 지원 비중을 살펴보면, 농업개발에 대한 지원 이 전체의 $29 \%$ 로 가장 높으며, 농업용수자원에 대한 지원 사업이 $19 \%$, 농업토지자원 지원 사 업이 $17 \%$, 농업정책 및 행정 지원 사업이 $10 \%$ 수준이다. 이외에도 농업연구(7\%), 작물생산 $(3 \%)$, 농업서비스(3\%), 동물검역(2\%), 농업대민지원(2\%), 축산(2\%) 등에 대한 지원사업도 이 루어지고 있다.

\section{〈그림 6〉 선진공여국의 동남아 농업의 주요 부문별 지원 비중(2011년)}

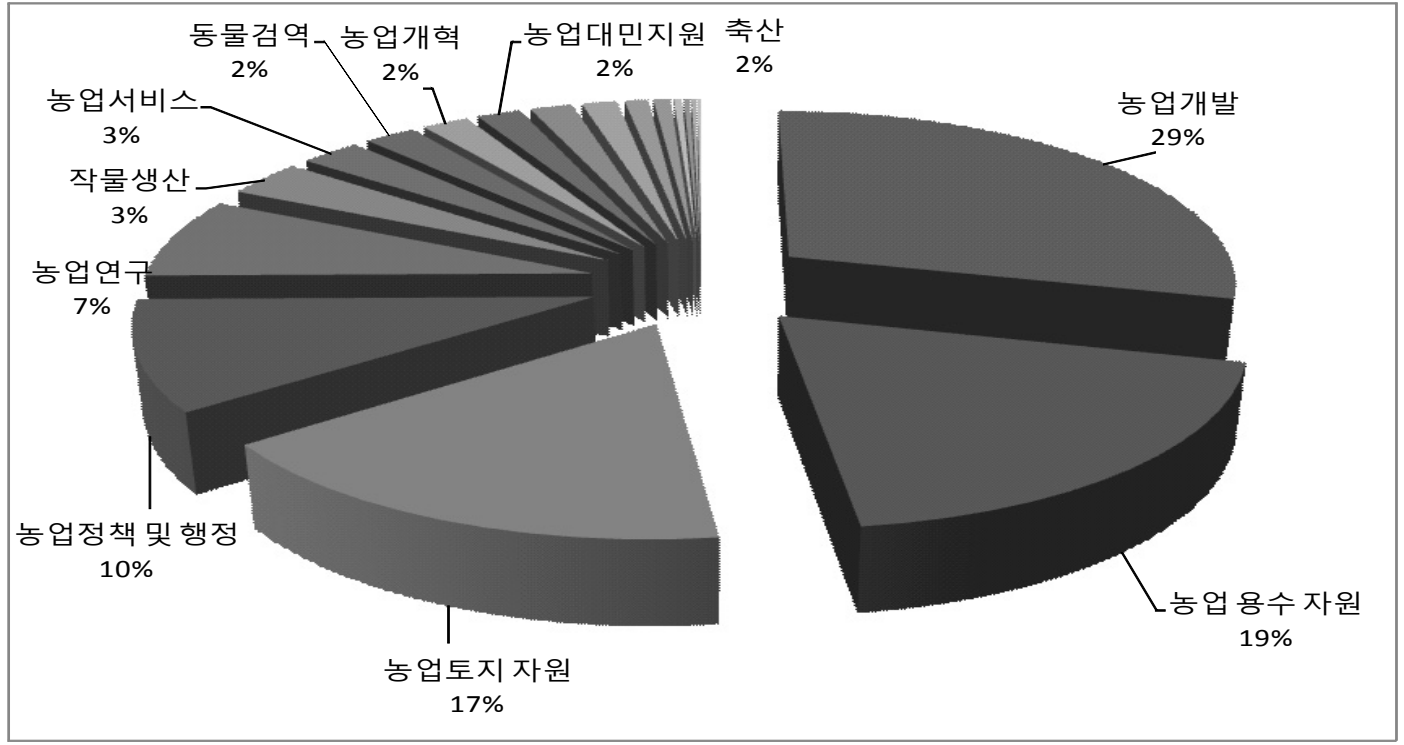

주 1 : 라오스, 캄보디아, 베트남, 필리핀, 인도네시아, 태국, 말레이시아에 대한 분야별 지원액을 합한 것임. 자료: OECD Creditor Reporting System 자료를 이용하여 저자 작성.

\section{IV. 동남아 농업분야에 대한 한국의 ODA 추진방향 모색}

한국이 지난 2006년부터 2010년까지 ODA를 통하여 개발도상국에 지원한 내역을 부문별로 살펴보면 전체 약 64.4 억 달러 중 농업부문에 대한 지원은 약 3 억 달러로 전체의 $4.6 \%$ 수준이 다(〈그림 7〉 참고). 즉 대부분의 $\mathrm{ODA}$ 는 지역개발(40.4\%), 교육(13.6\%), 수자원개발(12.1\%), 보건(10.5\%) 등에 지원되었다. 이는 개발도상국에서 이러한 지역개발과 교육 및 보건 등에 대 한 개발수요가 높기 때문으로 이해할 수 있다. 


\section{〈그림 7〉 한국의 부문별 지원현황(2006 2010)}

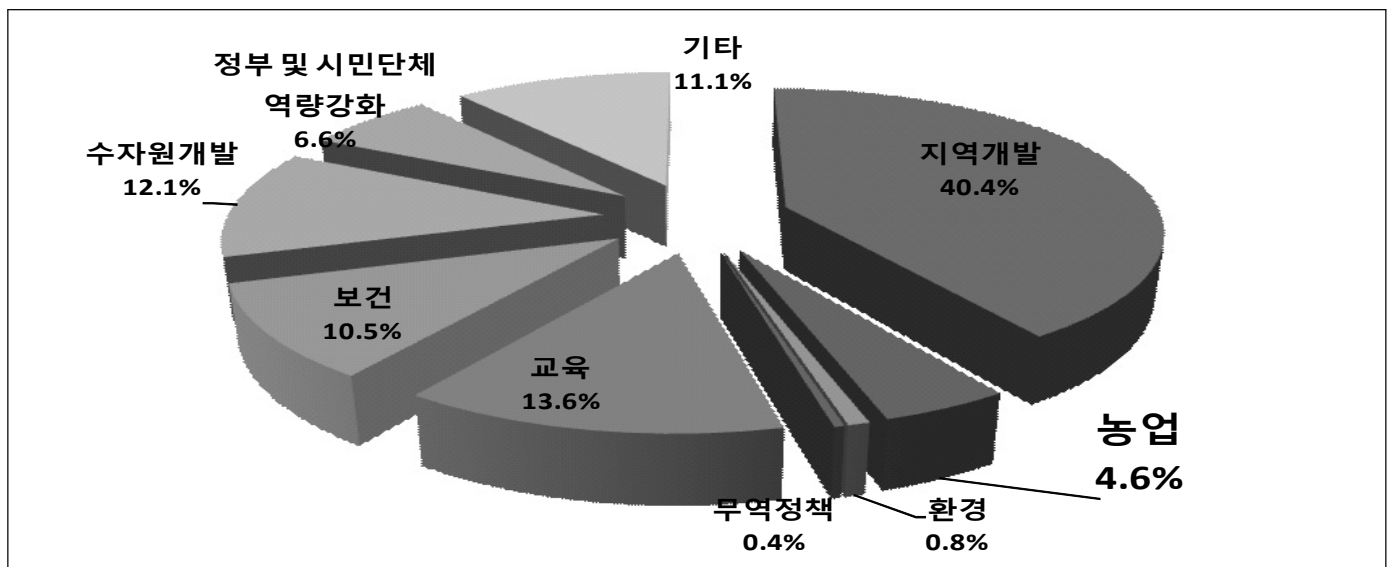

자료: OECD Creditor Reporting System 자료를 이용하여 저자작성. 권율 외(2012) p.117 참조.

한편, 한국의 동남아에 대한 농업 ODA 지원액은 지속적으로 증가하고 있고, 한국의 농업분 야 전체 ODA 중 동남아에 대한 농업 ODA 지원 비중도 2007년 이후 증가하는 추세이다. 지난 2010년 한국은 농업 ODA 중 약 $41.4 \%$ 를 동남아 지역에 지원하였다(〈그림 8〉참고). 이는 앞 에서 언급한 농업부문 $\mathrm{ODA}$ 비중(4.6\%)이 전반적으로 낮음에도 불구하고 상대적으로 농업부 문에서 동남아시아가 차지하는 비중이 다른 개발도상국에 비하여 상당히 높음을 의미하는 것 이다.

\section{〈그림 8〉 한국의 동남아에 대한 농업 ODA 지원액과 비중(2006 2010)}

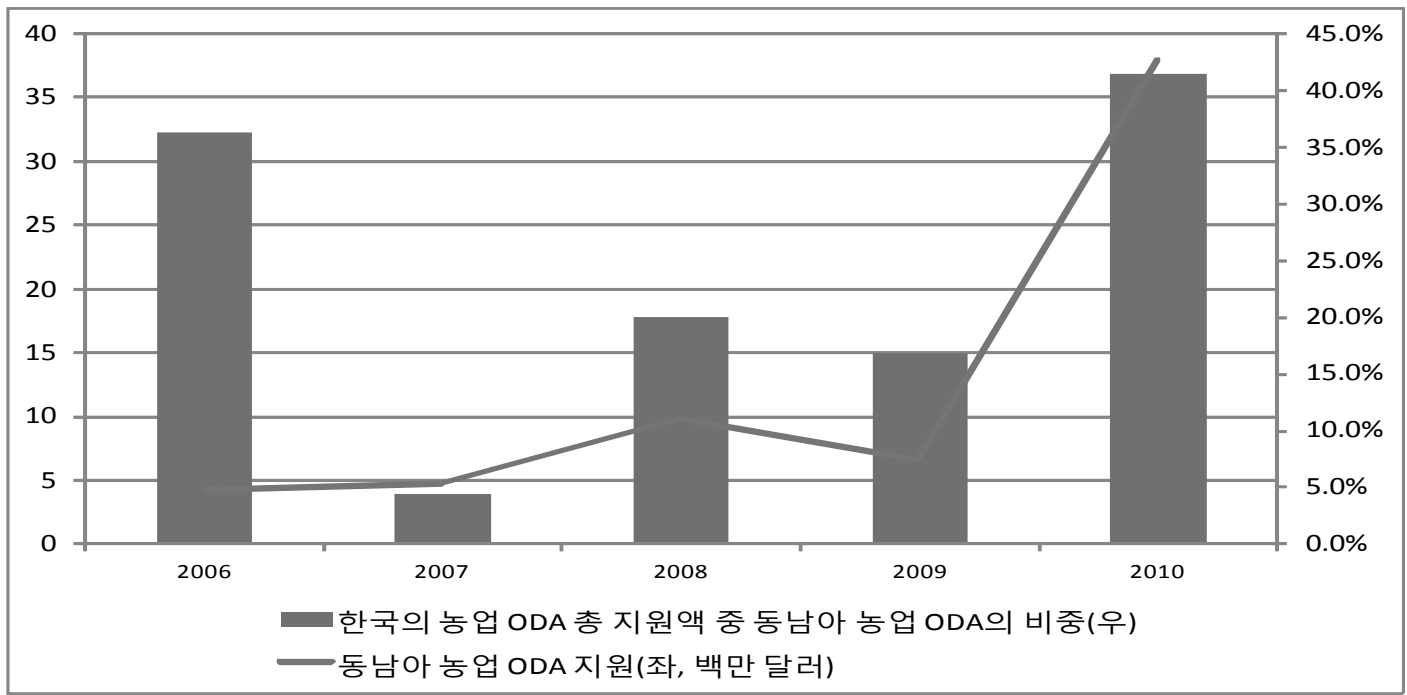

자료: OECD Creditor Reporting System 자료를 이용하여 저자 작성. 


\section{〈그림 9〉 한국의 동남아 개별국가에 대한 농업 ODA 지원액과 비중(2007 2011)}

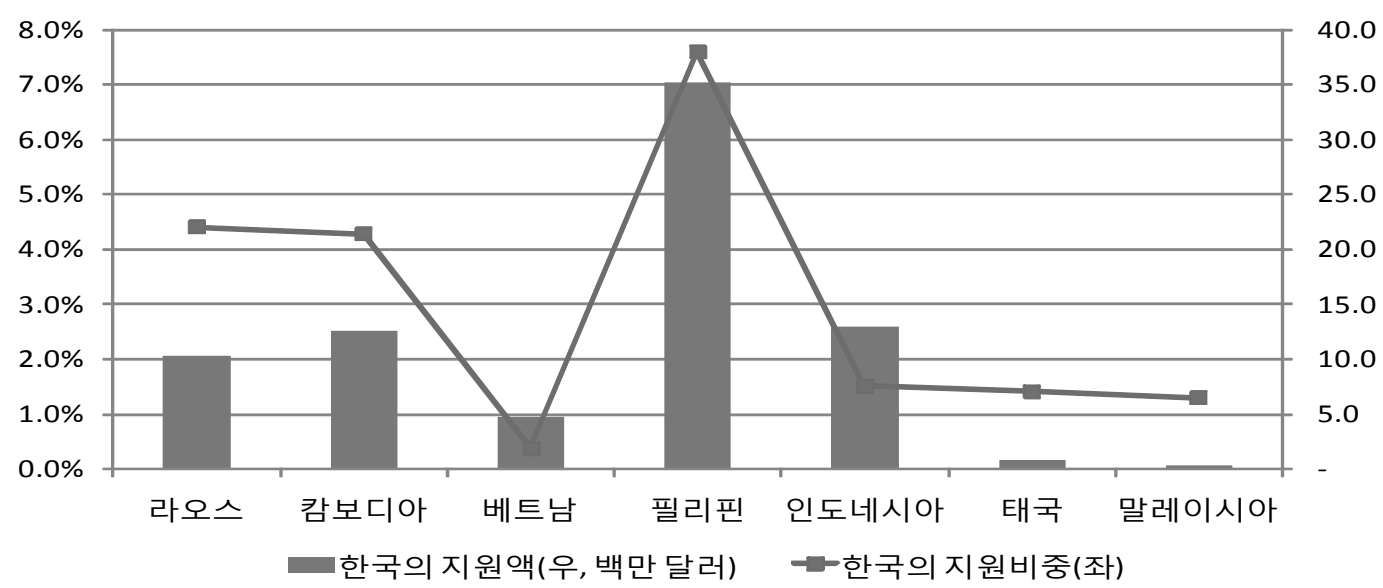

자료: OECD Creditor Reporting System 자료를 이용하여 저자 작성.

최근 5년간(2007 2011년) 한국의 동남아 개별 국가에 대한 농업 ODA 지원액을 살펴보면 필리핀에 대한 지원액이 3 천 5 백만 달러로 가장 많았고, 인도네시아 1 천 290 만 달러, 캄보디 아 1 천 260 만 달러, 라오스 1 천만 달러 순이었다(〈그림 9〉 참고). 전 세계의 동남아 농업부문 에 대한 $\mathrm{ODA}$ 지원액 중 한국의 지원비중을 살펴보면 필리핀의 경우 약 $7.6 \%$ 를 차지하고, 라 오스와 캄보디아가 각각 $4.4 \%, 4.3 \%$ 를 차지한다. 즉 이들 국가의 농업부문 개발협력 사업에 서 한국이 차지하는 비중이 결코 낮은 수준은 아닌 것이다.

이를 종합하면 동남아의 농업부문 ODA 지원 사업은 한국의 농업 부문 ODA 전체를 대표한 다고 해도 과언이 아니다. 동남아 농업부문에 대한 평가가 결과적으로는 한국의 농업 ODA 전 반에 대한 평가로 이어질 가능성이 농후한 것이다. 따라서 국제사회의 지원현황 및 방식과 최 대한 협력하면서 동남아의 농업 분야에 대한 개발수요를 적극적으로 발굴하여 동남아 농업분 야의 개발협력이 지역의 경제성장으로 연결될 수 있는 선순환 고리를 만드는데 적극적으로 기 여해야 할 것이다. 이를 추진하기 위해서는 다음과 같은 협력방향을 고려할 수 있을 것이다.

첫째, 농업부문에 대한 동남아 국가들의 개발수요를 적극적으로 발굴해야 한다. 전 세계적 으로는 농업개발과 농업용수 및 토지, 농업정책 및 행정 분야에 대한 지원이 상대적으로 많은 편이다. 하지만 이외에도 농업 기초연구, 작물생산, 농업서비스, 동식물검역, 농업개혁, 농업 인 지원, 축산, 농업협동조합, 농업투입요소, 농업교육, 농업금융, 대체농업개발, 수확후 관리 기술 및 시설, 수출작물 등에 대한 지원 사업도 이루어지고 있음을 상기해야 한다. 동남아의 경우 식량작물의 생산성 향상을 위하여 기반시설과 투입재에 대한 수요가 높고, 곡류의 가공 및 저장시설에 대한 수요도 점차 높을 것으로 예상된다. 육류의 경우 가공 및 유통시설에 대한 수요가 장기적으로 높을 것이다. 농업부문 적자구조를 가지고 있는 국가(예 : 필리핀, 캄보디 
아, 라오스, 미얀마)의 경우 이를 구조적으로 해결하면서도 수출농업 육성을 위한 지원이 절실 할 것으로 판단된다. 특히 이들 국가에서 한국의 농업분야 ODA 지원액이 다른 국가보다도 결 코 낮은 수준이 아님을 명심할 필요가 있다. 몇 가지 소수의 품목만을 수출하는 국가(예 : 말레 이시아, 태국 등)의 경우 다양한 수출농산품을 개발하고 보다 부가가치를 높이기 위한 개발수 요가 지속적으로 발생할 것이다. 이러한 분야에 대한 농업협력 사업을 지속적으로 추진하는 것은 양자간의 장기적인 경제협력 측면에서 큰 의미가 있는 것이다.

둘째, 국제사회의 지원동향을 지속적으로 살펴보면서 이들의 지원방식에도 적극 참여하고 장기적으로는 이를 주도할 수 있는 개발역량을 갖추어야 한다. 농업부문에 있어 국제적인 $\mathrm{ODA}$ 추세를 살펴보면 점차 다자간 기구를 통한 지원 사업이 증가하고 있음을 알 수 있다. 한 국은 동남아 농업분야 ODA 지원 사업을 양자 간 사업 위주로만 진행하였기 때문에 이제는 이 러한 다자간 기구를 통한 개발협력 사업에도 적극 참여할 필요가 있다. 다행스러운 것은 지난 2011년 '한-메콩 외교장관 회담'과 이후 선정된 6가지 중점 협력 분야 중 '농업 및 농촌개발'이 포함되어 있다. $\mathrm{ADB}$ 를 통한 GMS 프로그램 참여를 포함하여 메콩연구소(Mekong Institute) 와 메콩위원회(Mekong River Commission) 등을 통한 지역의 농업 및 농촌개발 사업에도 적 극 참여할 수 있을 것이다. 이를 통하여 한국의 동남아 농업부문에 대한 개발협력이 양자 간 지원 사업 위주에서 다자 간 협력 사업으로 한 단계 성숙하는 계기가 되어야 할 것이다.

셋째 농업부문에 대한 정부 및 민간 전문가를 지속적으로 육성해야 한다. 한국은 1960년 정 부 주도의 경제개발을 통하여 빠른 시간 내에 산업화를 이룩하였고, 1997년에는 IMF 외환위 기를 겪기도 했지만, 2010년에는 OECD DAC 회원국이 되어 국제사회의 리더로 성장할 수 있 는 기반을 마련하였다. 특히 정부는 2015년까지 ODA 규모를 2010년의 2 배로 늘릴 것을 국제 사회에 약속하였다. 한국의 전체 ODA 지원액 중 동남아에 대한 지원 규모가 높고 농업부문 $\mathrm{ODA}$ 중 동남아가 높은 비중을 차지하기 때문에 동남아 농업부문에 대한 개발협력 사업의 중 요성은 지속적으로 증가할 것이다. 따라서 동남아 농업부문의 협력 사업을 추진할 수 있는 정 부와 민간의 역량을 강화하는 것이 시급하다. 우선 농업의 부문별(예 : 농업정책, 농업생산기 술, 농업경영컨설팅 등)로 경험이 풍부한 전문가(또는 은퇴한 전문가)와 개발협력 사업에 적극 참여하고자 하는 젊은 층이 공동으로 협력사업을 추진하는 것도 하나의 방안이 될 수 있다. 지 난 2012년 말 도입된 정부의 협동조합 육성방안을 적극 활용하는 것도 필요하다. 정부는 이러 한 민간의 개발협력 역량을 강화시킬 수 있는 사업을 적극적으로 지원해야 할 것이다. 동남아 와 같은 해외 개도국에 대한 개발전문가를 적극 육성하고 이들이 현지의 개발이슈를 주도적으 로 발굴하도록 함으로써 한국이 해당 개발이슈를 국제적으로 주도하는 것이 중요하다. 이는 우리의 개발경험을 다른 개발도상국과 공유하는 것과 더불어 한국의 국제적 위상을 높이는데 기여할 것이다. 


\section{참고문헌}

\section{국문자료}

권율 - 김태윤 - 이재호 - 김유미. 2012. “동남아의 개발수요와 한국의 분야별 ODA 추진방안”. 대외경제 정책연구원.

김태윤 - 정재완 - 이재호 - 신민금 - 박나리. 2012. "한국의 메콩 지역개발 중장기 협력방안 : 농업, 인프라 및 인적자원개발을 중심으로”. 대외경제정책연구원.

\section{영문자료}

ADB. 2012. Key Indicators for Asia and the Pacific 2012. Asian Development Bank: Manila, Philippines.

FAO. 2010. FAO Statistical Yearbook. 2010.

Lucas, Robert E.B. and D. Verry, 1999. Restructuring the Malaysian Economy: Development and Human Resources. Macmillan Press LTD : Houndmills, Great Britain.

World Bank. 2007. World Development Report 2008. Agriculture for Development. Washington, DC : The World Bank.

\section{웹사이트}

FAO 통계DB((http : //faostat3.fao.org/home/index.html\#HOME)

OECD 통계DB(http : //stats, oecd.org/Index.aspx?datasetcode=CRS1\#) 